\title{
MUSCLE SATELLITE CELLS IN MALNOURISHED AND NUTRITIONALLY REHABILITATED CHILDREN
}

\author{
FAY M. HANSEN-SMITH ${ }^{1,2 *}$, D. PICOU ${ }^{1}$ and M. H. GOLDEN ${ }^{1}$ \\ 1 Tropical Metabolism Research Unit, University of the West Indies, Kingston (Jamaica) and \\ 2 Department of Anatomy, 4622 Medical Sciences II, University of Michigan, Ann Arbor, MI 48109 \\ (U.S.A.)
}

(Received 3 October, 1978)

(Accepted 4 December, 1978)

\section{SUMMARY}

Satellite cells were examined qualitatively and quantitatively in muscle biopsies from children when malnourished, during nutritional rehabilitation, and after clinical recovery. The proportion of satellite cell nuclei relative to myonuclei was significantly lower in malnourished subjects than in well-nourished age-matched controls $(4.5 \pm 1 \%$ vs. $8.1 \pm 1.0 \%$ ). The proportion of satellite cells remained low during the early period of "catch-up growth" but was significantly increased in the recovered subjects $(10.5 \pm$ $1.0 \%$ ). Satellite cells were small and their nuclei were heterochromatic in biopsies from the malnourished subjects. The cells were often partially segregated from the parent fiber by an external lamina. In recovering and recovered subjects many of the satellite cells enlarged, and the appearance of their nuclei and cytoplasmic organelles suggested a more active state. Intervention of external lamina between the satellite cell and the myofibre was uncommon in the recovered subjects.

\section{INTRODUCTION}

Muscle satellite cells, first described by Mauro (1961), are morphologically unspecialized mononucleate cells found within the external laminae of muscle fibres. Their presence both in normal and in pathological human muscle has been docu-

This work was supported by the Muscular Dystrophy Associations of America, who provided Dr. F. M. Hansen-Smith with a post-doctoral fellowship, and by the Wellcome Trust, who provided support for M. H. Golden and funds for an electron microscope.

Present address: Department of Anatomy, University of Detroit, School of Dentistry, 2985 East Jefferson, Detroit, MI 48207, U.S.A.

* To whom requests for reprints should be addressed. 
mented (Ishikawa 1966; Reger and Craig 1968; Schmalbruch and Hellhammer 1976; Wakayama 1976). Most of the information about satellite cells comes from animal studies. The nuclei of satellite cells, unlike the nuclei of the multinucleate fibres, are capable of mitotic division (Albrook et al. 1971). Proliferation of true myonuclei within the muscle fibres is accomplished by the fusion of daughter satellite cells with the muscle fibre after mitotic division by the satellite cells (Moss and Leblond 1971). During normal muscle growth the percentage of satellite cells declines as the fibres mature (Allbrook et al. 1971; Schultz 1974; Cardasis and Cooper 1975; Kelly 1978a, b). Although the primary role of the satellite cell is probably to provide a reserve of mitotically active nuclei for incorporation into the fibre, the satellite cell may also serve as a stem cell in regenerating muscle (Bischoff 1976; Snow 1977, 1978b). Certain conditions, such as denervation (Ontell 1974; Hanzlikova et al. 1975; Schultz 1978), hypertrophy (Schiaffino et al. 1972; Hanzlikova et al. 1975), or injury (Teravainen 1970) are reported to lead to an increase in the proportion of satellite cell nuclei relative to the total nuclei. An increase in the proportion of satellite cells has also been found in human muscle disorders (Wakayama 1976). In contrast, a decline in the relative satellite cell population has been associated with aging (Snow 1978a). Other conditions, such as testosterone-stimulation or deprivation (levator ani muscle; Venable 1966) or chronic dietary restriction (Hansen-Smith et al. 1977) have not been shown to have an effect on the satellite cell population, although early stages following these treatments were not studied.

The relationship between the state of the muscle fibre and the satellite cell population remains to be elucidated. Whereas the relative satellite cell population declines during normal muscle growth (Allbrook et al. 1971; Schultz 1974; Cardasis and Cooper 1975; Kelly 1978a, b) it increases during compensatory hypertrophic growth (Schiaffino et al. 1972; Hanzlikova et al. 1975). Dissimilar changes in the satellite cell population are also found in atrophic muscles (Venable 1966; Ontell 1974; Hansen-Smith et al. 1977; Snow 1978a). In the present study the satellite cells of human muscle have been examined in muscles which were severely atrophic as a result of protein-energy malnutrition, or which were undergoing compensatory growth as a result of nutritional rehabilitation. The goal of the study was to obtain a better understanding of the role of the satellite cell during atrophy and during compensatory growth of muscles which are not affected by a primary neuromuscular disease. In previous reports on similar subjects, malnourished children from the Tropical Metabolism Research Unit in Jamaica, it has been shown that both muscle mass (Reeds et al. 1978) and fibre size (Hansen-Smith et al. 1979) double during nutritional rehabilitation. Muscle DNA may also increase (Reeds et al. 1978), suggesting that satellite cell proliferation may occur during recovery. Other changes within the muscle fibres will be reported separately.

\section{METHODS}

Muscle biopsies were analyzed from 23 infants and children who were admitted to the Tropical Metabolism Research Unit in Jamaica for treatment of severe protein- 
energy malnutrition. The nutritional rehabilitation regimen has been described elsewhere (Ashworth et al. 1968). The patients were studied at one or more of the following clinical stages:

(a) Malnourished: before weight gain was evident (1-7 days after admission)

(b) Early and mid-recovery: rapid weight gain in progress (8-14 and 15 or more days after admission)

(c) Clinically recovered: Attainment of weight expected for a child of the same height (Nelson 1975) prior to discharge.

Clinical data relevant to these patients are shown in Table 1.

Samples of the vastus lateralis muscle of the subjects were obtained by percutaneous needle biopsy (Nichols et al. 1968). Thirteen of the patients were biopsied twice to assess sequential changes. For these paired biopsies, different sides were sampled on each occasion. The biopsy was well tolerated by all children. They moved their limbs freely immediately after the procedure, and there were no complications. Muscle samples from well-nourished control subjects were obtained incidentally to surgical procedures (Table 2). Full and informed parental consent was obtained for the biopsy of each child. The study was approved by the Ethics Committees at both institutions.

TABLE 1

ANTHROPOMETRIC FEATURES OF MALNOURISHED, RECOVERING, AND RECOVERED SUBJECTS

\begin{tabular}{|c|c|c|c|c|}
\hline & Malnourished & Early recovery & Mid-recovery & $\begin{array}{l}\text { Clinically } \\
\text { recovered }\end{array}$ \\
\hline $\mathbf{N}$ & 8 & 7 & 11 & 16 \\
\hline $\begin{array}{l}\text { Sex } \\
\text { M } \\
\text { F }\end{array}$ & $\begin{array}{l}7 \\
1\end{array}$ & $\begin{array}{l}7 \\
0\end{array}$ & $\begin{array}{l}7 \\
4\end{array}$ & $\begin{array}{r}12 \\
4\end{array}$ \\
\hline $\begin{array}{l}\text { Diagnosis }{ }^{\mathrm{a}} \\
\text { marasmus } \\
\text { marasmic-Kwashiorkor } \\
\text { undernourished } \\
\text { Kwashiorkor }\end{array}$ & $\begin{array}{l}3 \\
4 \\
0 \\
1\end{array}$ & $\begin{array}{l}3 \\
1 \\
2 \\
1\end{array}$ & $\begin{array}{l}3 \\
3 \\
0 \\
5\end{array}$ & $\begin{array}{l}6 \\
5 \\
1 \\
4\end{array}$ \\
\hline $\begin{array}{l}\text { At admission } \\
\text { age (mo) } \pm \mathrm{SE} \\
\text { body weight }(\mathrm{kg}) \pm \mathrm{SE}\end{array}$ & $\begin{array}{l}14.4 \pm 2.3 \\
5.44 \pm 0.49\end{array}$ & $\begin{array}{l}17.4 \pm 2.3 \\
6.97 \pm 0.55\end{array}$ & $\begin{array}{l}15.7 \pm 1.4 \\
6.58 \pm 0.42\end{array}$ & $\begin{array}{l}14.8 \pm 1.4 \\
6.06 \pm 0.46\end{array}$ \\
\hline $\begin{array}{l}\text { At biopsy } \\
\text { body weight }(\mathrm{kg}) \pm \mathrm{SE} \\
\% \text { expected weight } / \text { height }^{\mathrm{b}} \\
\pm \mathrm{SE} \\
\text { days after admission }\end{array}$ & $\begin{array}{l}5.46 \pm 0.49 \\
68.3 \pm 1.7 \\
4.3 \pm 0.9\end{array}$ & $\begin{array}{l}7.81 \pm 0.60 \\
81.1 \pm 2.4 \\
10.3 \pm 0.9\end{array}$ & $\begin{array}{l}7.54 \pm 0.39 \\
80.5 \pm 2.0 \\
26.6 \pm 4.8\end{array}$ & $\begin{array}{l}8.75 \pm 0.44 \\
97.3 \pm 1.3 \\
60.8 \pm 8.0\end{array}$ \\
\hline Recovery time (days) $\pm \mathrm{SE}$ & $60.2 \pm 8.1$ & $38.1 \pm 6.9$ & $58.4 \pm 9.4$ & $60.8 \pm 8.0$ \\
\hline
\end{tabular}

a Lancet (1970).

b Nelson, W. E. (1975). 
TABLE 2

SATELLITE CELLS IN WELL-NOURISHED SUBJECTS

\begin{tabular}{|c|c|c|c|c|c|c|}
\hline Subject & Sex & $\begin{array}{l}\text { Age } \\
\text { (mo) }\end{array}$ & $\begin{array}{l}\text { Weight } \\
(\mathrm{kg})\end{array}$ & Diagnosis & Muscle & $\begin{array}{l}\% \text { Satellite } \\
\text { cells }\end{array}$ \\
\hline 1 & $\mathrm{~F}$ & 6 & 6.4 & $\begin{array}{l}\text { congenital hip } \\
\text { dislocation }\end{array}$ & rectus femorus & 6.6 \\
\hline 2 & $\mathrm{~F}$ & 19 & 10.0 & abdominal hernia & rectus abdominus & 10.1 \\
\hline \multirow[t]{2}{*}{3} & M & 23 & 16.9 & $\begin{array}{l}\text { congenital hip } \\
\text { dislocation }\end{array}$ & rectus femorus & 7.6 \\
\hline & & & & & mean & $8.1 \pm 1.0$ \\
\hline
\end{tabular}

The muscle samples were fixed in $2 \%$ phosphate-buffered glutaraldehyde, postfixed in $1 \% \mathrm{O}_{\mathrm{s}} \mathrm{O}_{4}$, dehydrated, and embedded in plastic blocks. The orientation of the samples was random. Thin "silver" or "gold" sections were cut from two blocks for each biopsy and were mounted on 300 mesh grids. The sections were stained with uranyl acetate and lead citrate and subsequently examined with a Corinth 500 or a Hitachi 11 A electron microscope. All nuclei within the basal lamina of the muscle fibres in each section were counted. In the few instances in which the two blocks selected yielded fewer than 100 nuclei, a third block was also examined, to bring the total nuclei to a minimum of 100 . The nuclei within the external lamina were classified as either myonuclei or satellite cell nuclei. For the purpose of the study a satellite cell was defined as a mononucleate cell that was enclosed within the muscle fibre within a common external lamina but separated from the fibre by its cell membrane and the plasma membrane of the sarcolemma. The count also included cells which were partially separated from the parent fibre by the intrusion of the external lamina.

TABLE 3

PERCENTAGE OF SATELLITE CELL NUCLEI IN MALNOURISHED, RECOVERING, AND RECOVERED SUBJECTS

\begin{tabular}{|c|c|c|c|c|}
\hline & Malnourished & Early recovery & Mid-recovery & $\begin{array}{l}\text { Clinical } \\
\text { recovery }\end{array}$ \\
\hline N (biopsies) & 8 & 7 & 11 & 16 \\
\hline Total nuclei ${ }^{a}$ & $242 \pm 47$ & $199 \pm 20$ & $180 \pm 21$ & $176 \pm 21$ \\
\hline$\%$ Satellite nuclei ${ }^{a}$ & $4.5 \pm 0.1^{\mathrm{b}, \mathrm{c}}$ & $6.7 \pm 0.7^{b}$ & $7.2 \pm 1.0$ & $10.5 \pm 1.0$ \\
\hline Total satellite cells & & & & \\
\hline examined & 100 & 92 & 120 & 275 \\
\hline $\begin{array}{c}\text { Satellite cells with basal } \\
\text { lamina intrusion }(\%)\end{array}$ & $\begin{array}{l}27 \\
(27)\end{array}$ & $\begin{array}{l}17 \\
(18.5)\end{array}$ & $\begin{array}{l}14 \\
(11.7)\end{array}$ & $\begin{array}{l}4 \\
(1.5)\end{array}$ \\
\hline
\end{tabular}

a Per biopsy \pm SEM.

b Significantly lower $(P<0.05)$ than clinically recovered subjects.

c Significantly lower $(P<0.05)$ than well-nourished controls. 


\section{RESULTS}

The percentage of satellite cell nuclei in muscle from well-nourished control patients ranged from 6.6-10.1 (Table 2). The mean percentage of satellite cell nuclei in the biopsies from malnourished patients was significantly lower than controls (Table 3 ). The mean proportion of satellite cells increased only slightly during early and midrecovery. However, in biopsies from the clinically recovered patients the mean percentage of satellite cells was significantly greater than either during malnutrition or early recovery. Values for the recovered patients were within or above the range of the normal children of the same age.

The percentage of satellite cells increased between the first and the second biopsy, in all but two subjects, regardless of the time interval (Fig. 1). (Examination of the patient's records and muscle morphology in the biopsies did not reveal any factor which might explain the $50 \%$ reduction in the satellite cell population of two patients during recovery.) The rates of increase in the satellite cell population varied widely between subjects. When the recovery times were related to the percentage of the total recovery time (Fig. 2) it was apparent that the largest increments in the satellite cell population occurred during the latter half of the recovery process. In only one subject was a rapid early increase observed. The satellite cell population of the recovered subjects appeared to be related to the patients' age at recovery because a significantly lower percentage $(6.9 \pm 0.8 \%)$ of satellite cells was found in younger subjects ( $\leq 12 \mathrm{mo}$ ) than in older subjects $(\geq 18 \mathrm{mo} ; 11.6 \pm 1.0 \%$ ). Although a plot of age vs. satellite cell nuclei for the recovered children (Fig. 3) suggested a positive correlation it was not significant $(r=0.376)$. This is because of one particularly high value, as elimination of this high value resulted in a highly significant correlation $(r=$ $0.701, P<0.01$ ).

Satellite cells in muscle from the malnourished subjects were invariably small

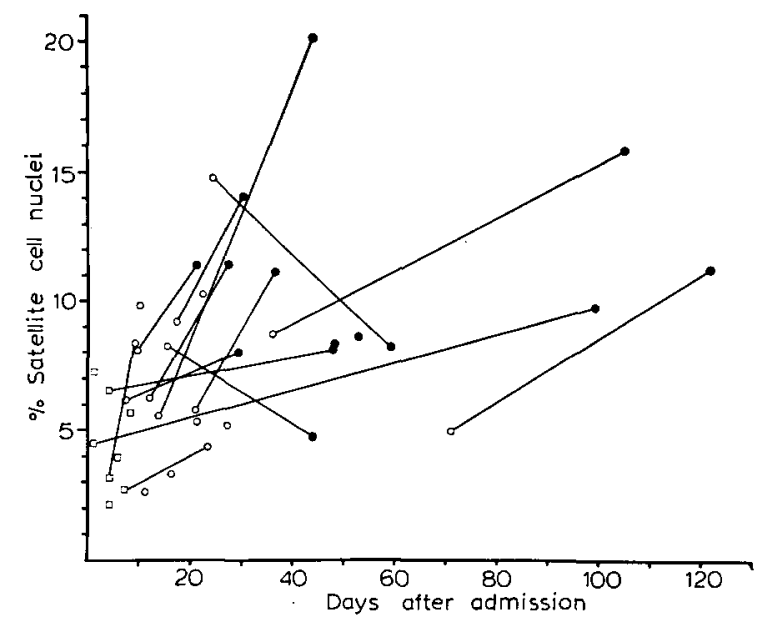

Fig. 1. Muscle satellite cell population in malnourished $(\square)$, recovering $(\bigcirc)$, or clinically recovered subjects (O). 

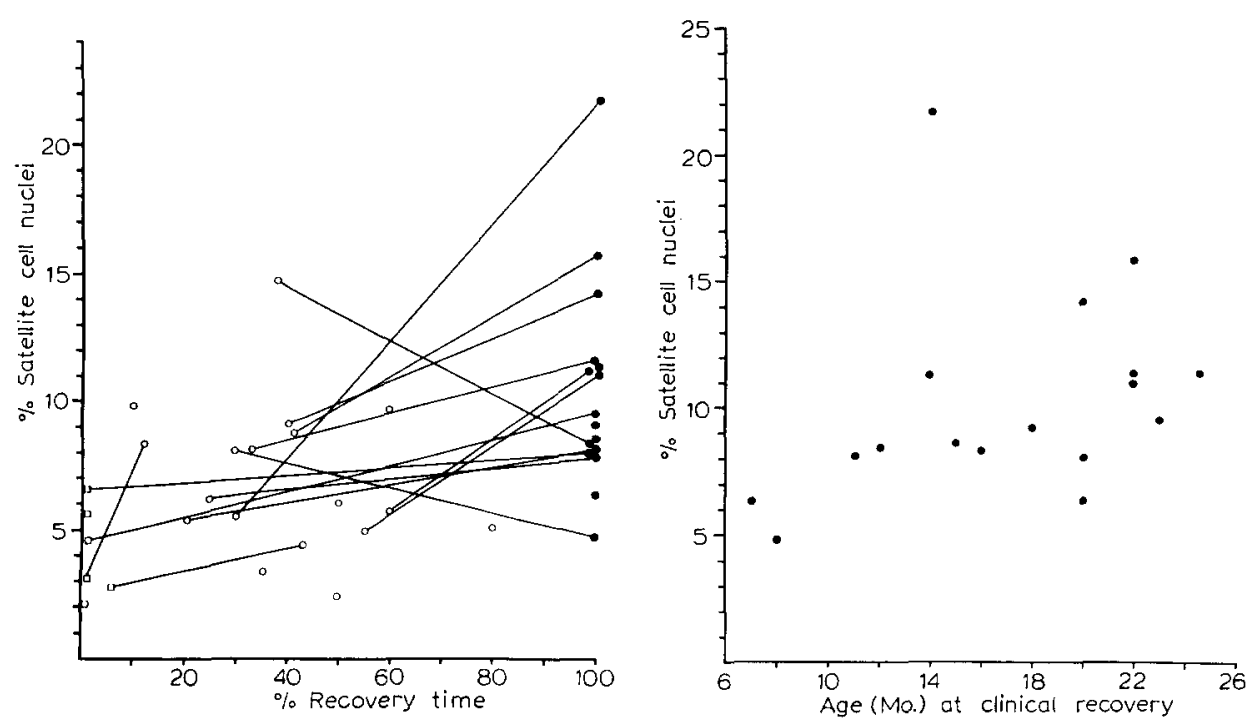

Fig. 2. Muscle satellite cell population in malnourished $(\square)$, recovering ( $\bigcirc$ ), or clinically recovered subjects (O). Percent recovery time indicates time of biopsy (days elapsed after admission) as a percentage of total recovery time.

Fig. 3. Muscle satellite cell population in recovered subjects in relation to their ages.

(Fig. 4). There was a paucity of cytoplasm around the nuclei, and few organelles were observed. The nuclei of these satellite cells were usually very heterochromatic, and in some cases they appeared pyknotic. Although the chromatin of the myonuclei was also very condensed, that of the satellite cell nuclei was even more condensed in comparison.

During the earliest stages of recovery some of the satellite cells became elongated, and rough endoplasmic reticulum (RER) and other organelles became more evident. During the later stages of recovery and at clinical recovery 3 basic types of satellite cells could be defined (Figs. 5 and 6). The first type was a small cell with little cytoplasm. In size it resembled the satellite cells found in malnourished subjects but the nucleus was generally less heterochromatic. The second type was very elongated and contained prominent RER (which was sometimes dilated), Golgi apparatus, free ribosomes, a few mitochondria, and in some cells a centriole. The nuclei were elongated, flattened, and moderately heterochromatic. The 3rd type of cell was also elongated, but it appeared to be larger in diameter. The cytoplasm of these cells was noticeably less electron-dense than that of the first two cell types. Randomly dispersed microtubules and microfilaments were sometimes found in these cells. The nuclei tended to be relatively euchromatic and sometimes contained a nucleolus. Whereas RER was less conspicuous in these cells, free ribosomes and small ribosomal clusters were more conspicuous. A Golgi apparatus, mitochondria, studded vesicles, and occasional centrioles were also observed. None of the satellite cells contained glycogen, even though glycogen was densely deposited in many of the muscle fibres or between the fibre and the satellite cell during recovery. The enlargement of satellite 

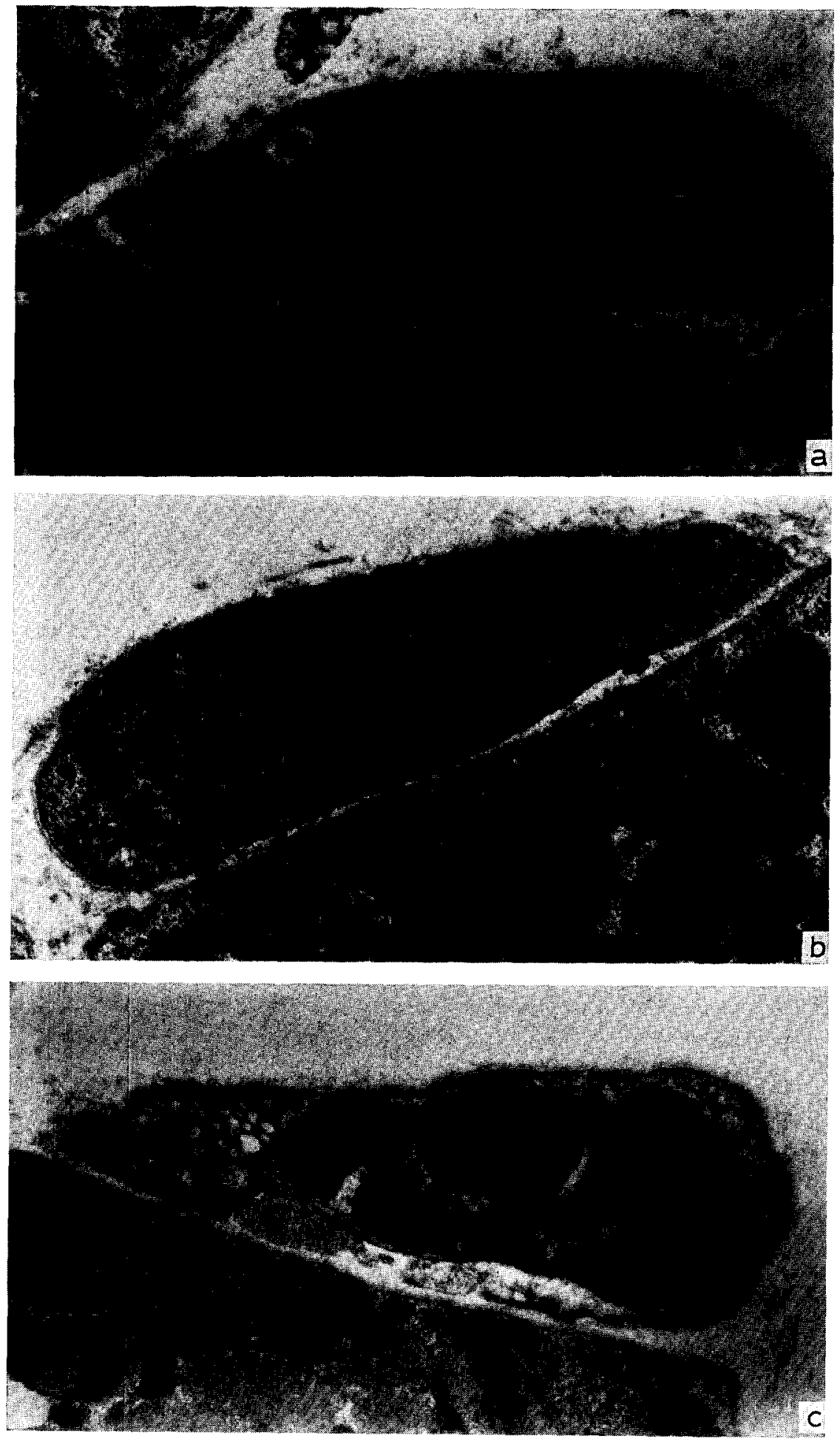

Fig. 4. Satellite cells from malnourished subjects contain little cytoplasm. One or two layers of external lamina may be found between the satellite cell and the parent fibre $(b, c) . a \times 18,200 ; b \times 14,700$; $c \times 14,700$. 

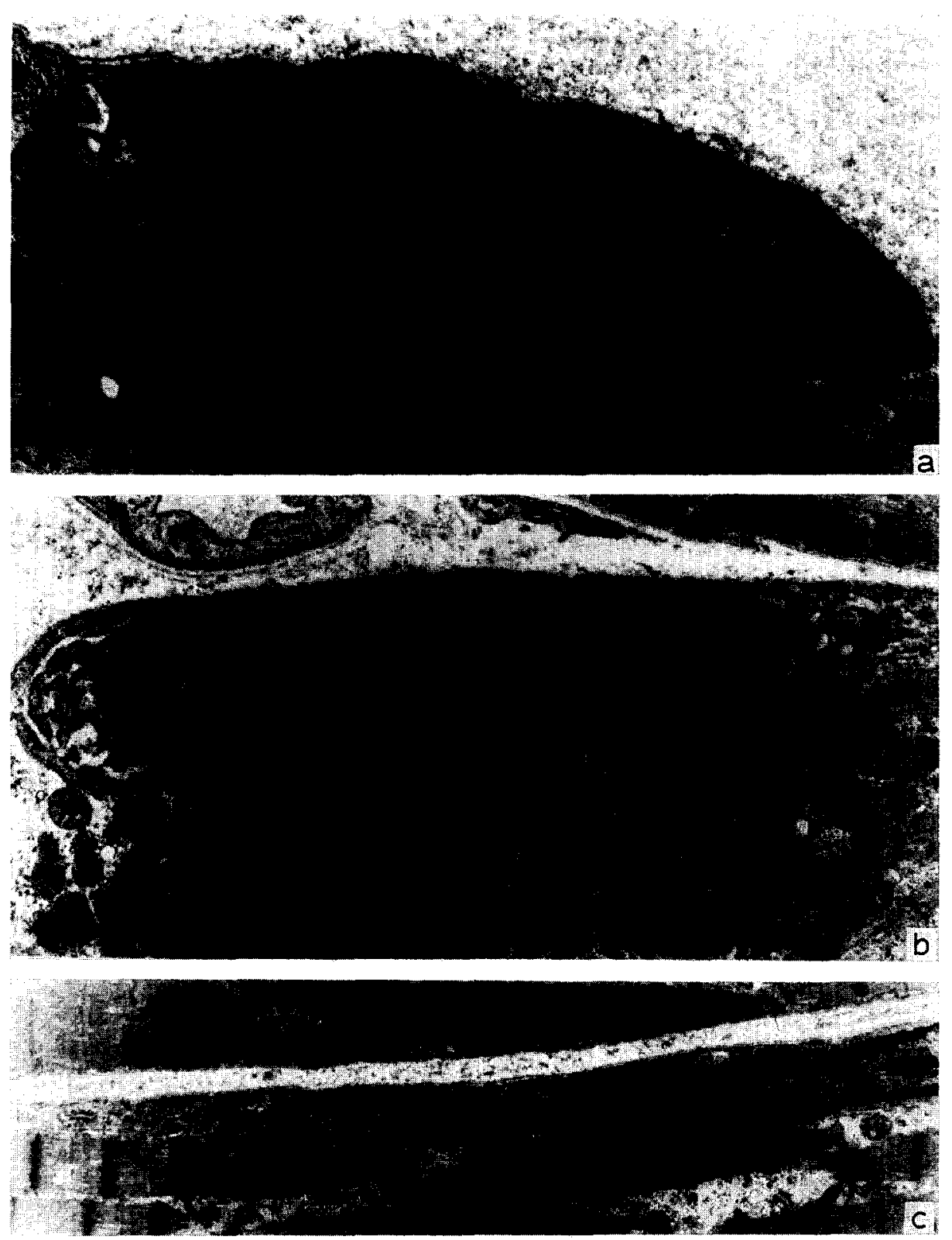

Fig. 5. Satellite cells from recovering $(a, c)$ and clinically recovered $(b)$ subjects. The cells may be small $(a)$ or elongated $(b, c)$, with prominent RER and Golgi. $a \times 11,700 ; b \times 10,400 ; c \times 8,100$.

cells during recovery was emphasized by the common finding in recovering and recovered subjects of portions of satellite cells which did not contain a nucleus and which were therefore not included in the estimation of satellite cell frequency. In contrast, all satellite cells observed in the biopsies from malnourished subjects contained a portion of the nucleus. 

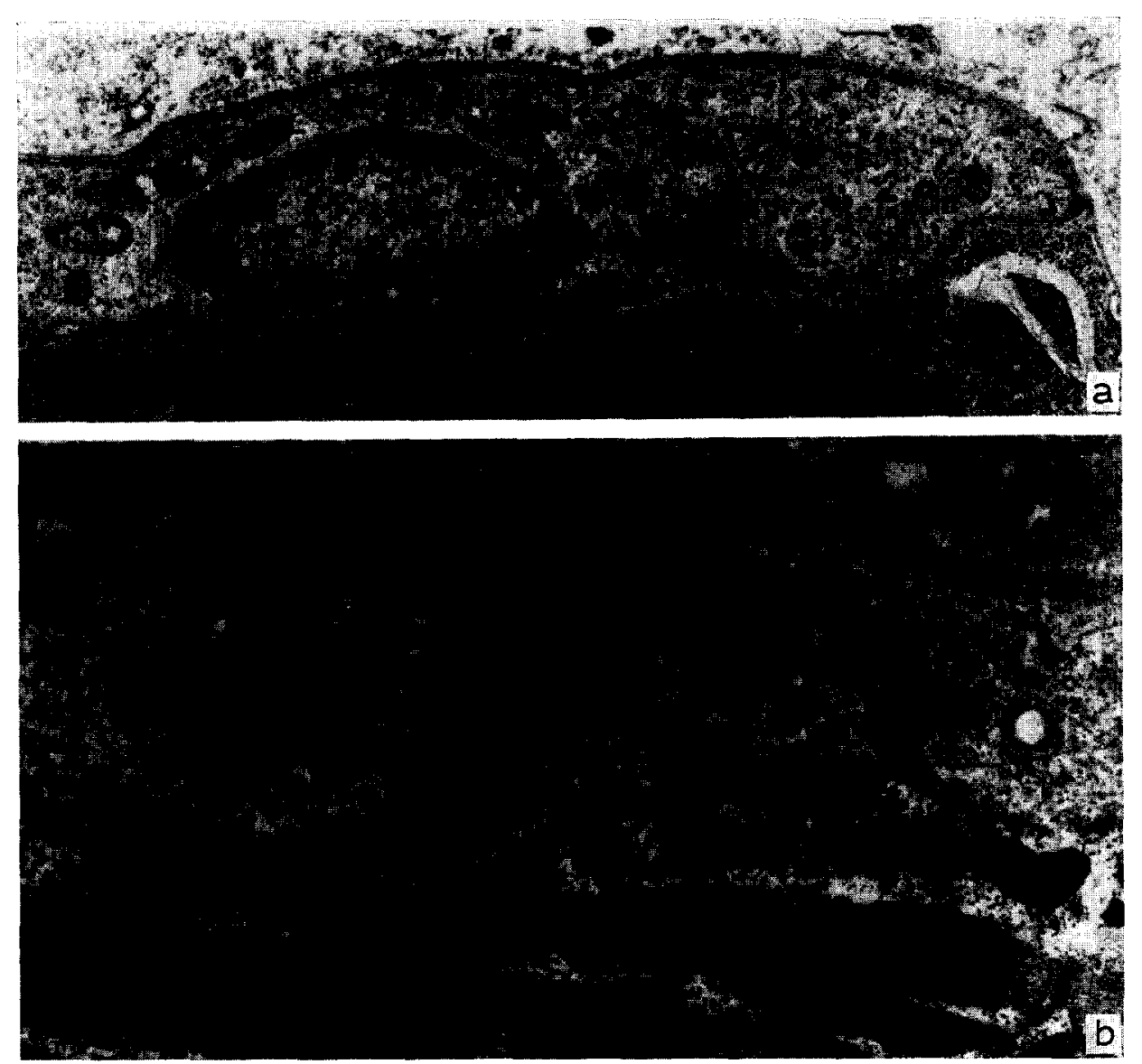

Fig. 6. Satellite cells from recovered subjects $(a, b)$. The cells are enlarged and electron-lucient. Little RER is found, but small ribosomal clusters are present. Microfilaments and microtubules are found in $b$, and a centriole is found in $a . a \times 13,500 ; b \times 19,100$.

In biopsies from all clinical stages except the malnourished stage a satellite cell was commonly found immediately adjacent to a myonucleus (Fig. 7). In addition, the cytoplasm of some of the satellite cells in recovering and recovered subjects was sometimes incompletely separated from the muscle fibre. These satellite cells were presumed to be fusing with the parent fibre (Fig. 8).

During recovery, the appearance of the majority of the satellite cells was related to the state of the specific fibre in which they were situated, regardless of their proximity to the myonuclei. For example, fibres in which myonuclei maintained an inactive appearance, i.e. thin, elongated, with condensed chromatin, also contained satellite cells whose nuclei were in a similar state. In contrast, satellite cells tended to be enlarged and their nuclei were more euchromatic in muscle fibres whose nuclei were euchromatic (Fig. 7).

All of the satellite cells included in the count shared a common external lamina with the parent fibre. However, in many cases external laminae also intervened 

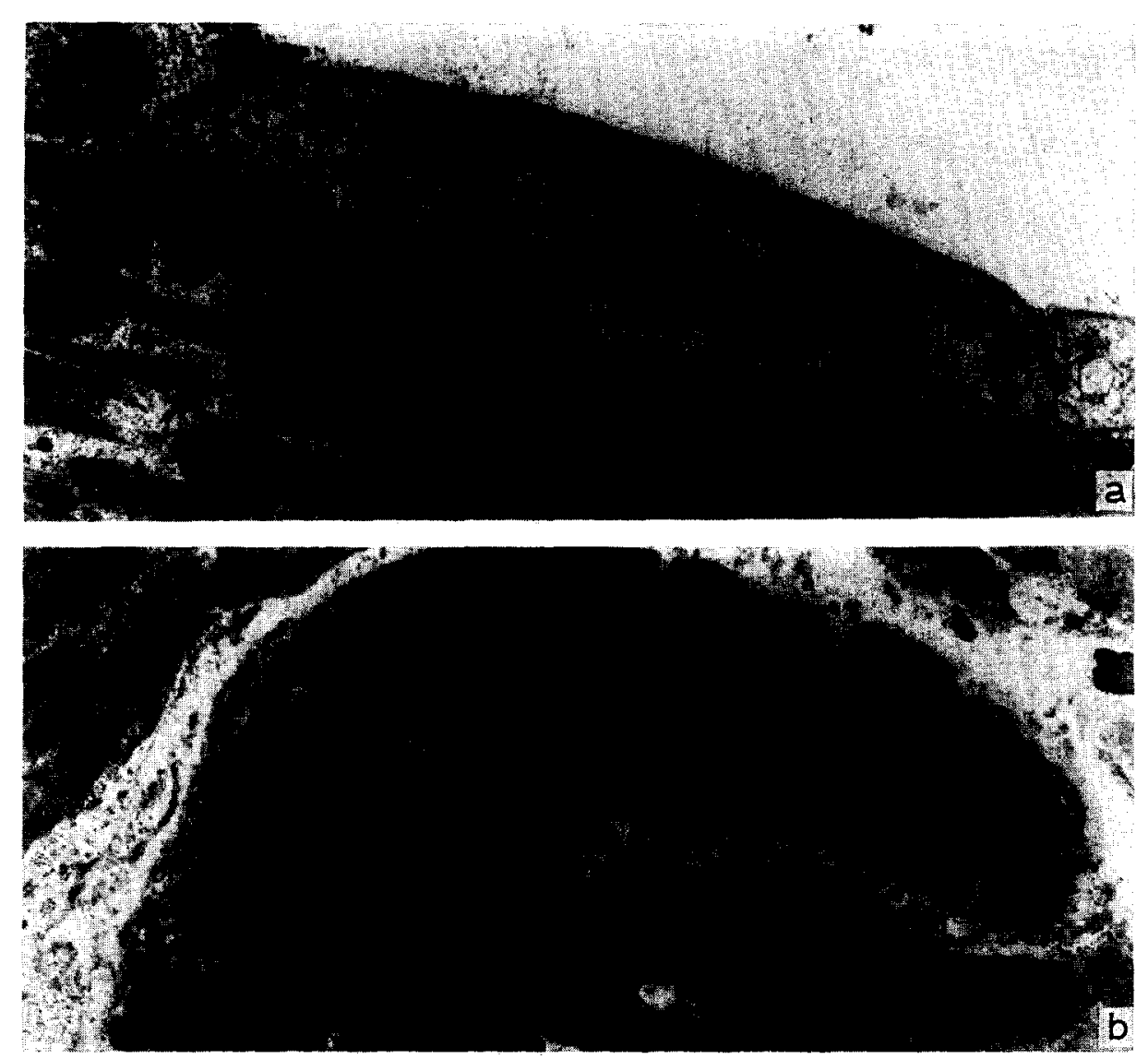

Fig. 7. Satellite cells from recovered subjects $(a, b)$. Chromatin distribution in satellite cells is comparable to that in adjacent myonuclei. Satellite cell nucleus in $a$ contains a nucleolus. Glycogen is found in the space between the fibre and the satellite cell in $b . a \times 8,100 ; b \times 11,500$.

between the satellite cell and the fibre. This was particularly evident in biopsies from malnourished subjects, but became less prevalent as recovery progressed (Table 3 ). In some cases the external lamina intruded only a short distance between the fibre and the satellite cell (Fig. 5a), while in other cases, the external lamina completely lined the fibre or the inner border of the satellite cell or both (Fig. 4). These cells were included in the counts of satellite cells because the outermost external lamina of the satellite cell was shared with the basal lamina of the parent fibre. Also found near the fibres were undifferentiated cells which may have been derived from satellite cells. They were surrounded by an external lamina but they were completely separated from the basal lamina of the fibre in the plane of section (Fig. 10). These cells were not considered in the count and were not recorded separately because it was impossible to distinguish with certainty whether they were derived from satellite cells or were pericapillary cells.

The satellite cells of the well-nourished subjects generally resembled the smallest of the satellite cells found in the recovering subjects. More elongated cells similar to the second type were sometimes observed, but the third type of satellite cell was not 


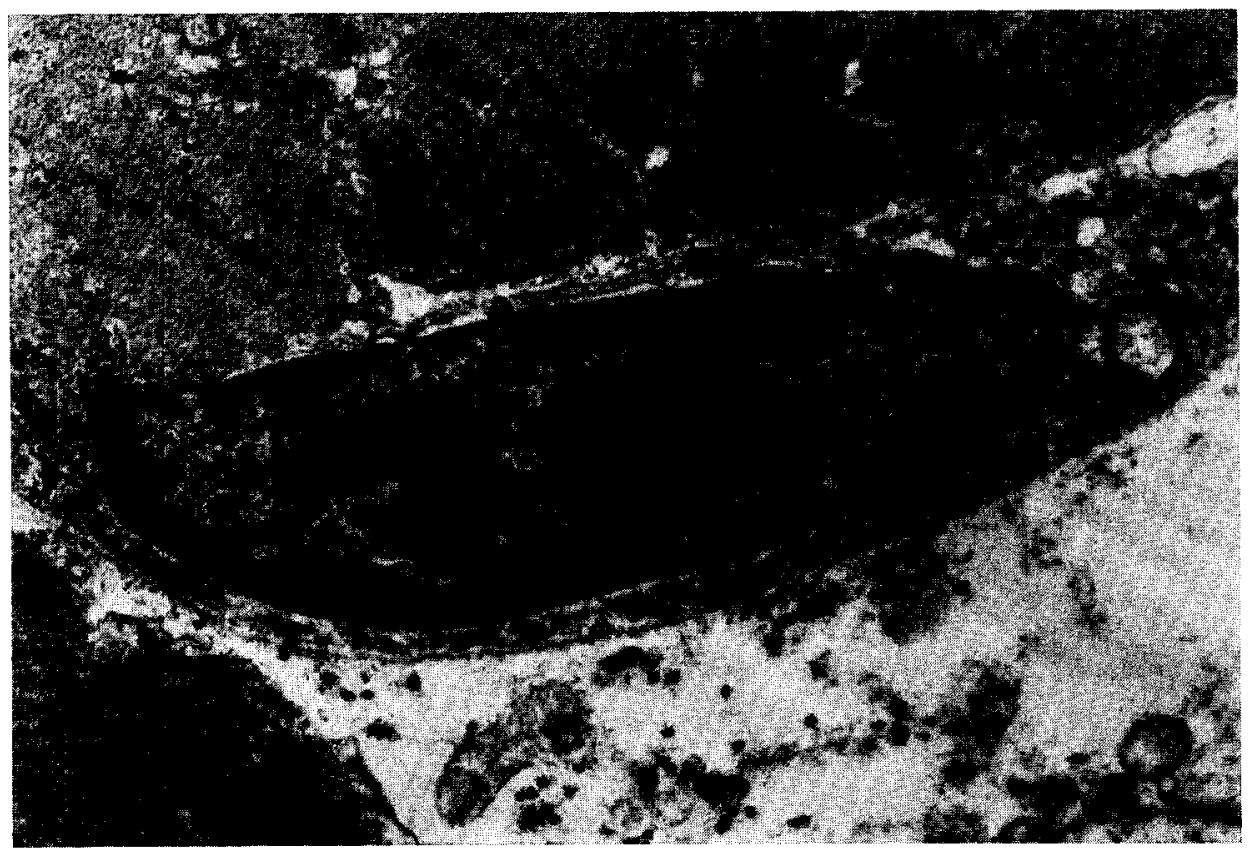

Fig. 8. Satellite cell from recovered subject is incompletely separated from the parent fibre, suggesting fusion of the satellite cell with the fibre. $\times 26,000$.

found in any of the three biopsies. Intrusion of external lamina between the satellite cell and the myofibre was never observed.

\section{DISCUSSION}

This study shows that the muscle satellite cell population in children is affected by malnutrition. The proportion of satellite cells in the malnourished subjects was significantly lower than that of well-nourished children of the same age. The proportion of satellite cells increased during nutritional rehabilitation. Distinctive changes in the appearance of the satellite cells occurred concurrently.

The functional significance of the morphological changes in the satellite cells remains to be assessed. The appearance of the satellite cells in the malnourished

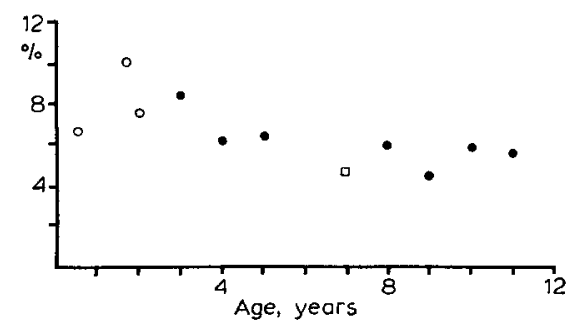

Fig. 9. Satellite cell populations in well-nourished children of different ages $(O:$ present study, Schmalbruch and Hellhammer 1976, $\square$ : Wakayama 1976). 


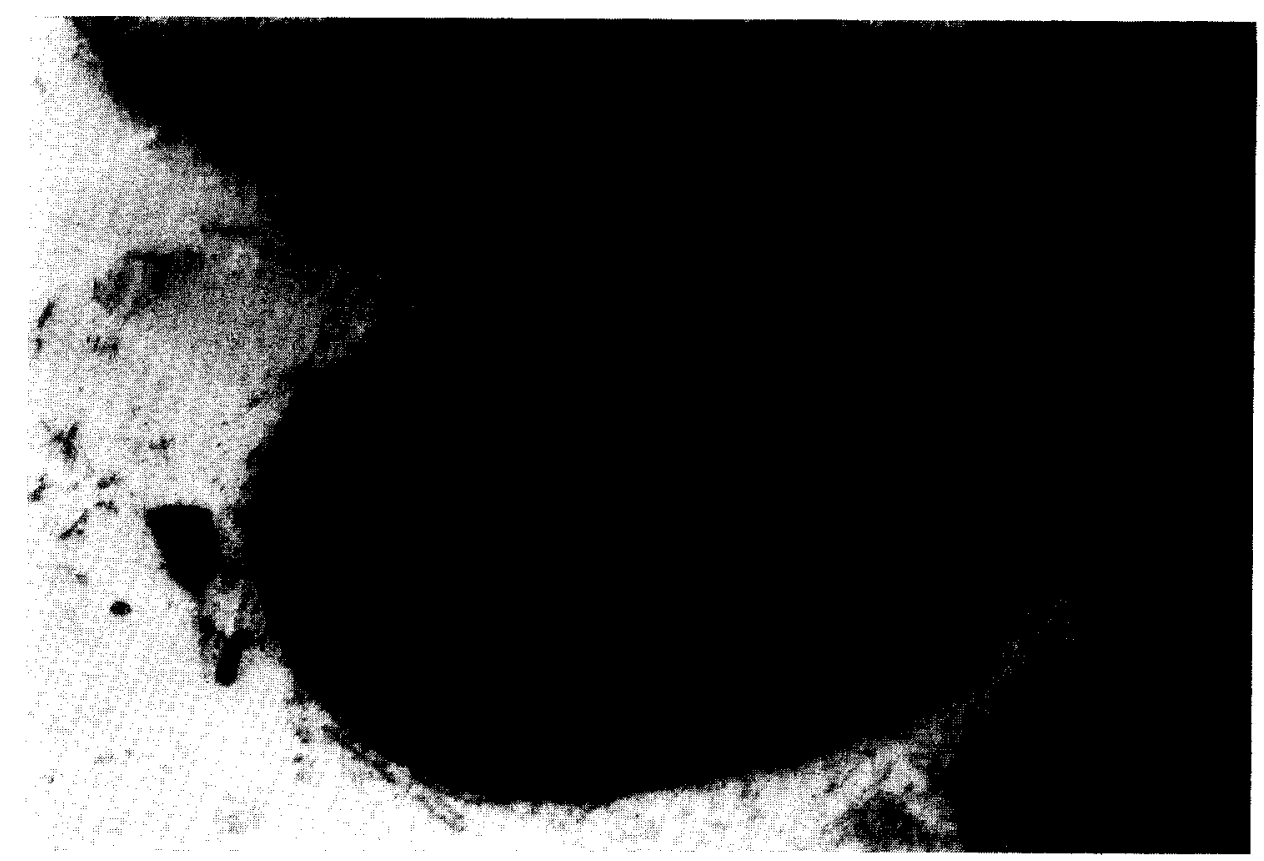

Fig. 10. Mononucleate cell adjacent to a myofibre in a malnourished subject. The cell is surrounded by an external lamina; it may be a satellite cell which has detached from the fibre, but it cannot be distinguished from a capillary pericyte with certainty. $\times 22,500$.

subjects was suggestive of an inactive metabolic state. However, after nutritional rehabilitation was begun, the appearance of the cells changed toward a more "active" state. The prevalence of RER in the satellite cells during early recovery and, to some extent also in later recovery suggests that protein is initially synthesized for use elsewhere. Schultz (1975) has found that the RER-containing satellite cells incorporate $\left[{ }^{3} \mathrm{H}\right]$ uridine, whereas the RER-deficient cells do not. The identity and the function of the proteins are not known. It is conceivable that a messenger protein is synthesized. As recovery progressed, the RNA of many of the satellite cells tended to be more dispersed. In addition, the cells became enlarged, and their nuclei sometimes contained nucleoli. Thus, a change in the nature of protein synthesis by the cells occurred. In addition, microtubules and microfilaments were found in the satellite cells during the latter stages of recovery. These have also been found in satellite cells during normal muscle growth (Schultz 1976) in denervated muscle (Ontell 1975) and in diseased human muscle (Wakayama 1976), but their significance is not clear.

Despite the apparent "activation" of satellite cells during early rehabilitation, no significant increase in the percentage of satellite cells was evident until the subjects had clinically recovered. The nature of the relationship of satellite cells to the cellular changes in the parent fibre has not been established. A major increment in fibre size occurs during the early rehabilitation period, although proliferation of myofibrillar material appears to be associated with later stages of rehabilitation (Hansen-Smith, unpublished observation). Proliferation of satellite cells may be initiated by a 
requirement for more myonuclei for RNA synthesis. Subsequent fusion of the cells with the myofibre may facilitate protein synthesis by the fibre. Kelly (1978b) has suggested a relationship between changes in the satellite cell population and the protein metabolism of the muscle fibre.

The counts of satellite cell nuclei give little information about dynamic changes of the satellite cell population. Changes in the proportion of satellite cells may result from a change in the rate of proliferation of the cells or from a change in the rate of their incorporation into the fibre. It seems likely that the rate of proliferation of the cells is slowed by malnutrition, since experimental models show that malnutrition during maturation interferes with muscle DNA synthesis (Spence and Hansen-Smith 1978). Because it appeared that the fibres in malnourished subjects were attempting to discard satellite cells by synthesizing external lamina between fibre and satellite cells, it would seem likely that the rate of incorporation was probably also reduced. During recovery, fewer satellite cells were separated from the parent fibre by external lamina. This means that more of the satellite cells were available for fusion with the parent fibre. The finding of paired satellite and myonuclei during recovery may indicate two daughter cells following mitosis, one of which has fused with the parent fibre. The frequency of these paired nuclei during recovery suggests that proliferation of satellite cells may be more rapid during recovery. Their rate of proliferation and/or incorporation into the parent fibre may have increased or remained unchanged, but it seems unlikely that the rates would decrease during recovery.

Whether the total number of nuclei within the fibres increases during recovery cannot be determined from this study. However, analyses of total DNA in muscle of malnourished and recovered subjects suggest that increases in muscle DNA may occur during recovery (Reeds et al. 1978). The distribution of nuclei between muscle fibres and the interstitium does not change between malnutrition and recovery (HansenSmith et al. 1978). If the compensatory growth of muscle fibres during recovery from malnutrition reflects a process comparable to experimental compensatory hypertrophy (Schiaffino et al. 1976), it is likely that the population of myofibre nuclei increases during recovery, and that this increase is mediated by the incorporation of satellite cells into the fibre.

The intrusion of external lamina between the satellite cell and the muscle fibre has been observed in normal muscle in animals and in muscle from aging rats in denervated and in pathological human muscle (Ontell 1975; Schultz 1976; Wakayama 1976; Kelly 1978a; Snow 1978) as well as the present study. The status of such "satellite cells" is controversial A rigid definition of the satellite cell would exclude those cells which are partially or completely separated from the parent fibre by basal lamina. In the present study the elimination of such satellite cells from the count would have had no significant effect on the percentage of satellite cells in recovered subjects, whereas it would have depressed the percentage even further in the malnourished subjects. Kelly (1978a) has suggested that the cells in question should be included in the counts. A number of quantitative studies on satellite cells have been done by light microscopy, using differences in nuclear chromatin as a criterion for distinction between myonuclei and satellite nuclei. Intrusion of basal lamina obviously would not have been detected in 
these studies. It should be noted that the observations in the present study suggest that differences in nuclear chromatin may be inadequate for distinction of satellite cells, particularly when the muscle under study is undergoing changes.

Information concerning the role of satellite cells during normal muscle development has been derived almost exclusively from laboratory animal studies. The data presented for well-nourished children in this study contribute toward a better understanding of normal muscle growth in humans. A plot of this data and other available data for children under twelve years of age (Fig. 9) suggest a slight decline in the satellite cell population for the first 4-5 years, when the values approach those of adult muscle.

\section{ACKNOWLEDGEMENTS}

We thank Dr. C. L. Carpenter and Dr. R. N. Hensinger for providing surgical biopsies, the Nursing Staff of the Tropical Metabolism Research Unit for the skillful care of our patients, and the Department of Pathology, University of the West Indies, for use of their facilities.

\section{REFERENCES}

Allbrook, D. B., M. F. Han and A. E. Hellmuth (1971) Population of muscle satellite cells in relation to age and mitotic activity, Pathology, 3: 233-243.

Ashworth, A., R. Bell, W. P. T. James and J. C. Waterlow (1968) Caloric requirements of children recovering from protein-calorie malnutrition, Lancet, $2: 600-602$.

Bischoff, R. (1974) Enzymatic liberation of myogenic cells from adult rat muscle, Anat. Rec., 180: 645-662.

Cardasis, C. A. and G. W. Cooper (1975) An analysis of nuclear numbers in individual muscle fibers during differentiation and growth - A satellite cell-muscle fiber growth unit, J. exp. Zool., 191 : $347-358$.

Hansen-Smith, F. M., D. Picou and M. Golden (1978) Quantitative analysis of nuclear population in muscle from malnourished and recovered children, Pediat. Res., 12: 167-170.

Hansen-Smith, F. M., D. L. Van Horn and M. G. Maksud (1978) Cellular response of rat quadriceps muscle to chronic dietary restrictions, $J$. Nutr., 108: 248-255.

Hansen-Smith, F. M., D. Picou and M. Golden (1979) Growth of muscle fibers during recovery from severe malnutrition in Jamaican infants, Brit. J. Nutr., In press.

Hanzlikova, V., E. V. Mackova and P. Hnik (1975) Satellite cells of the rat soleus muscle in the process of compensatory hypertrophy combined with denervation, Cell Tiss. Res., 160: 411-421.

Ishikawa, H. (1966) Electron microscopic observations of satellite cells with special reference to the development of mammalian skeletal muscles, Z. Anat. Entw.-Gesch., 125: 43-63.

Kelly, A. M. (1978a) Perisynaptic satellite cells in the developing and mature rat soleus muscle, Anat. Rec., 190: 891-904.

Kelly, A. M. (1978b) Satellite cells and myofiber growth in the rat soleus and extensor digitorum longus muscle, Develop. Biol., 65: 1-10.

Lancet (1970) Classification of infantile malnutrition, $2: 302$.

Mauro, A. (1961) Satellite cell of skeletal muscle fibers, J. biophys. biochem. Cytol., 9: 491-500.

Montgomery, R. D. (1962) Muscle morphology in infantile protein malnutrition, J. clin. Path., 15: 511-521.

Moss, F. P. and C. P. Leblond (1971) Satellite cells as a source of nuclei in muscles of growing rats, Anat. Rec., 170: 421-436.

Nelson, W. E. (1975) Textbook of Pedictrics, Saunders, Philadelphia, PA.

Nichols, B. L., C. F. Hazlewood and D. J. Barnes (1968) Percutaneous needle biopsy of quadriceps muscle for potassium analysis in normal children, J. Pediat., 72: 840-844. 
Ontell, M. (1974) Muscle satellite cells - A validated technique for light microscopic identification and a quantitative study of changes in their population following denervation, Anat. Rec., 178: 211-228.

Ontell, M. (1975) Evidence for myoblastic potential of satellite cells in denervated muscle, Cell Tiss. Res., 160: 345-353.

Reeds, P. J., A. A. Jackson, D. Picou and N. Poulter (1978) Muscle mass and composition in malnourished infants and children and changes seen after recovery, Pediat. Res., 12: 613-618.

Reger, J. F. and A.S. Craig (1968) Studies on the fine structure of muscle fibers and associated satellite cells in hypertrophic human deltoid muscle, Anat. Rec., 169:483-500.

Schmalbruch, H. and U. Hellhammer (1976) The number of satellite cells in normal human muscle, Anat. Rec., 185: 279-288.

Schiaffino, S., S. P. Bormiali and M. Aloisi (1972) Cell proliferation in rat skeletal muscle during early stages of compensatory hypertrophy, Virchows Arch. B. Cell Path., $11: 268-273$.

Schiaffino, S., S. P. Bormiali and M. Aloisi (1976) The fate of newly formed satellite cells during compensatory hypertrophy, Virchows Arch. B. Cell Path., 21: 113-118.

Schultz, E. (1974) A quantitative study of the satellite cell population in postnatal mouse lumbrical muscle, Anat. Rec., 180: 589-596.

Schultz,E. (1975) Protein synthesis in satellite cells of skeletal muscles, as visualized by radioautography after injection of ${ }^{3} \mathrm{H}$-tyrosine, Anat. Rec., $181: 472$.

Schultz, E. (1976) Fine structure of satellite cells in growing skeletal muscle, Amer. J. Anat., 147: 49-70.

Schultz, E., M. C. Gibson and J. Cohen (1978) Mitotic activity of satellite cells in normal and denervated adult rat muscle as visualized by radioautography after injection of ${ }^{3} \mathrm{H}$-thymidine, Anat. Rec., 190: 535.

Snow, M. H. (1977) Myogenic cell formation in regenerating rat skeletal muscle injured by mincing, Part 2 (An autoradiographic study), Anat. Rec., 188: 201-218.

Snow, M. H. (1978a) The effects of aging on satellite cells in skeletal muscles of mice and rats, Cell Tiss. Res., 185: 399-408.

Snow, M. H. (1978b) An autoradiographic study of satellite cell differentiation into regenerating myotubes following transplantation of muscles in young rats, Cell Tiss. Res., 186: 535-540.

Spence, C. A. and F. M. Hansen-Smith (1978) Comparison of the chemical and biochemical composition of thirteen muscles of the rat after dietary protein restriction, Brit. J. Nutr., 39: 647-658.

Teravainen, H., (1970) Satellite cells of striated muscle after compression injury so slight as not to cause degeneration of the muscle fibers, $Z$. Zellforsch., 103: 320-327.

Venable, J. H. (1966) Constant cell populations in normal, testosterone-deprived and testosteronestimulated levator ani muscles, Amer. J. Anat., 119: 263-270.

Wakayama, Y. (1976) Electron microscopic study on the satellite cell in the muscle of Duchenne muscular dystrophy, J. Neuropath. exp. Neurol., 35: 532-539. 